\title{
Origin-specific molecular signatures of dissolved organic matter in the Lena Delta
}

\author{
I. Dubinenkov $\cdot$ R. Flerus $\cdot$ P. Schmitt-Kopplin • \\ G. Kattner • B. P. Koch
}

Received: 3 July 2014/Accepted: 31 October 2014/Published online: 15 November 2014

(C) Springer International Publishing Switzerland 2014

\begin{abstract}
Large Arctic rivers discharge significant amounts of dissolved organic matter (DOM) into the Arctic Ocean. We sampled natural waters of the Lena River, the Buor-Khaya Bay (Laptev Sea), permafrost melt water creeks, ice complex melt water creeks and a lake. The goal of this study was to characterize the molecular DOM composition with respect to different water bodies within the Lena Delta. We aimed at an identification of source-specific DOM molecular markers and their relative contribution to DOM of different origin. The molecular characterization was
\end{abstract}

Responsible Editor: Karsten Kalbitz.

Electronic supplementary material The online version of this article (doi:10.1007/s10533-014-0049-0) contains supplementary material, which is available to authorized users.

I. Dubinenkov $(\bowtie) \cdot$ R. Flerus · G. Kattner · B. P. Koch Ecological Chemistry, Alfred-Wegener-Institut Helmholtz-Zentrum für Polar und Meeresforschung, Am Handelshafen 12, 27570 Bremerhaven, Germany e-mail: ivan.dubinenkov@awi.de

Present Address:

R. Flerus

Biological Oceanography, GEOMAR Helmholtz Centre for Ocean Research, Düsternbrooker Weg 20, 24105 Kiel, Germany

P. Schmitt-Kopplin

Research Unit Analytical BioGeoChemistry, Helmholtz

Zentrum München, German Research Center for

Environmental Health, Ingolstädter Landstraße 1,

85764 Neuherberg, Germany performed for solid-phase extracted DOM by Fourier transform ion cyclotron resonance mass spectrometry (FT-ICR MS). Average dissolved organic carbon concentrations in the original samples were $490 \pm 75 \mu \mathrm{mol} \mathrm{C} \mathrm{L}{ }^{-1}$ for riverine and bay samples and $399 \pm 115 \mu \mathrm{mol} \mathrm{C} \mathrm{L}{ }^{-1}$ for permafrost melt water creeks. Average TDN concentrations were elevated in the permafrost melt waters (19.7 \pm $7.1 \mu \mathrm{mol} \mathrm{N} \mathrm{L}{ }^{-1}$ ) in comparison to the river and the bay (both $13.2 \pm 2.6 \mu \mathrm{mol} \mathrm{N} \mathrm{L}{ }^{-1}$ ). FT-ICR MS and statistical tools demonstrated that the origin of DOM in the Lena Delta was systematically reflected in its molecular composition. Magnitude weighted parameters calculated from MS data $\left(\mathrm{O} / \mathrm{C}_{\mathrm{wa}}, \mathrm{H} / \mathrm{C}_{\mathrm{wa}}, \mathrm{C} / \mathrm{N}_{\mathrm{wa}}\right)$ highlighted preliminary sample discrimination. The highest $\mathrm{H} / \mathrm{C}_{\mathrm{wa}}$ of 1.315 was found for $\mathrm{DOM}$ in melt

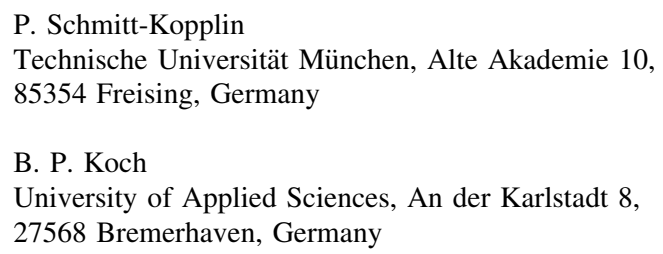


water creeks in comparison to 1.281 for river and 1.230 for the bay samples. In the bay samples we observed a higher fraction of oxygen-rich components which was reflected in an $\mathrm{O} / \mathrm{C}_{\mathrm{wa}}$ ratio of 0.445 in comparison to 0.425 and 0.427 in the river and creeks, respectively. From the southernmost location to the bay a relative depletion of nitrogenous molecular markers and an enrichment of oxidized DOM components occurred. The highest contribution of nitrogenous components was indicative for creeks reflected in a $\mathrm{C} / \mathrm{N}_{\mathrm{wa}}$ of 104 in comparison to 143 and 176 in the river and bay, respectively. These observations were studied on a molecular formula level using principal component and indicator value analyses. The results showed systematic differences with respect to water origin and constitute an important basis for a better mechanistic understanding of DOM transformations in the changing Arctic rivers.

Keywords Arctic $\cdot$ Lena Delta $\cdot$ Permafrost $\cdot$ DOM . FT-ICR MS · Molecular markers

\section{Introduction}

The large rivers discharge huge amounts of freshwater into the Arctic Ocean. Arctic rivers drain vast areas characterized by variable vegetation and soil conditions (Bhatt et al. 2010; Lantuit et al. 2009) which are important sources of dissolved organic carbon (DOC) in the Arctic Ocean. Dissolved organic matter (DOM) is involved in a wide range of biogeochemical processes in the Arctic river watersheds (Yenisei, Ob, Lena, Indigirka, Kolyma, Mackenzie and Yukon) (Roehm et al. 2009; Wickland et al. 2012) and in the Arctic Ocean (Amon and Meon 2004; Dittmar and Kattner 2003). It supports microbial growth, affects primary production and therefore plays an important role in carbon and nutrient cycling (Le Fouest et al. 2013).

The water (McClelland et al. 2004; Peterson et al. 2002) and DOC discharge (Frey and McClelland 2009; Semiletov et al. 2011) into the Arctic Ocean are expected to change in future due to increasing temperatures and subsequent permafrost thawing and degradation (Zhao-ping et al. 2010). The largest and most vulnerable source of organic matter is represented by the organic-rich permafrost (Engelhaupt
2008). The estimated amount of organic carbon accumulated in permafrost is $\sim 1,700 \mathrm{Pg}$ of carbon (Tarnocai et al. 2009). The degradation and mobilization of this carbon pool would have critical implications for microbial processes, primary production and carbon cycling in the Arctic and the Arctic Ocean Basin interior (Frey and McClelland 2009; Schuur et al. 2008). DOM represents the most mobile part in these soils and is therefore of particular importance when studying organic carbon fluxes in changing permafrost environments. DOM is a highly complex mixture of organic compounds with different chemical properties (Thurman 1985). In the context of global element cycles it remains an unresolved issue which fractions of DOM are bioavailable or recalcitrant (Abbt-Braun and Frimmel 2002; Jiao et al. 2011) and it is one of the most important challenges in the field of DOM research to develop a better mechanistic understanding of the processes, which determine the wide range of residence times (Flerus et al. 2012; Lechtenfeld et al. 2014).

The Lena River is one of the largest rivers in the Arctic, and permafrost underlies $78-93 \%$ of the watershed with continuous permafrost extending south to $50^{\circ} \mathrm{N}$ (Zhang et al. 1999). Estimates for the annual discharge of DOC range between 4.1-4.9 $\mathrm{Tg} \mathrm{C}_{\text {year }}{ }^{-1}$ (Dittmar and Kattner 2003; Opsahl et al. 1999) and 5.6-5.8 $\mathrm{Tg} \mathrm{C}$ year $^{-1}$ (Holmes et al. 2012; Raymond et al. 2007). The annual discharge of the Lena River particulate organic carbon (POC) was estimated to be $0.38 \mathrm{Tg} \mathrm{C}$ year $^{-1}$ (Semiletov et al. 2011) which is less than one tenth of the contribution of DOC emphasizing the importance of DOM to the total organic carbon discharge. Late summer runoff of the Lena River is dominated by DOM input from organic-rich soils, ice complexes, and the mires of northern Asia. Hydrologic processes mobilize organic carbon stored in the permafrost soils and carry it downstream (Guo et al. 2007).

The majority of existing studies, which addressed carbon fluxes, sources and transformation of organic matter in the Arctic used bulk DOC, isotopic signatures and targeted biomarker approaches. Several studies used isotopic and biomarker approaches to investigate DOM and particulate organic matter fluxes in the Buor-Khaya Bay of the Laptev Sea (Karlsson et al. 2011) and other Arctic regions (Cooke et al. 2009; Vonk et al. 2008; Yunker et al. 1995). Carbon isotope and lipid biomarker studies in the Buor-Khaya 
Bay demonstrated that a large terrestrial input from the Lena River leaves a significant imprint on the surface water POC composition (Karlsson et al. 2011). The young fluvial/alluvial POC pool is relatively buoyant, organic carbon rich and bioavailable, which is consistent with clear spatial trends of rapidly degrading POC throughout the Buor-Khaya Bay surface water (Karlsson et al. 2011). Most of the annual discharge of lignin (an unambiguous terrestrial tracer) occurs during the 2 months of spring freshet with extremely high lignin concentrations and a lignin phenol composition indicative of fresh vegetation from boreal forests. At low flow conditions DOM was dominated by older, soil, peat and wetland-derived DOC (Doxaran et al. 2012). Despite several studies on DOM molecular markers in the Lena River (Doxaran et al. 2012; Kraberg et al. 2013; Lara et al. 1998), there is still a gap in our understanding of regional biogeochemical processes involving DOM from different sources (i.e., riverine, soil and permafrost).

In the permafrost influenced Kolyma River the composition and age of DOM was analyzed during different seasons using radiocarbon analysis (Neff et al. 2006). The bulk DOM in winter and spring is modern with a high concentration of lignin. At the end of summer and in autumn, the age of DOM becomes significantly older indicating that the DOM generation changed from surface to deep soils or other terrestrial sources of old and more refractory DOM. The Lena River and Kolyma River may have similar mechanisms and trends of organic matter release. However, integral DOM signals such as isotopic composition or radiocarbon age and more specific signals from other molecular markers have to be combined with new analytical tools and markers on a molecular level for a better understanding of the Lena River Delta ecosystem processes. Identification of new groups of biomarkers will also broaden our current knowledge of changing processes in the Arctic rivers caused by climate change.

There is still a gap of knowledge of the quality of DOM in Arctic rivers which is an important factor to assess its bioavailability and degradability. Untargeted analytics such as Fourier transform ion cyclotron resonance mass spectrometry (FT-ICR MS) allows to cover the complexity of the molecular pattern of DOM and to identify molecular markers and their transformation pathways in the pool of DOM molecules (Stubbins et al. 2010). Molecular markers, which demonstrate not only the most dramatic but also individual changes, may also represent major biogeochemical processes. FT-ICR MS already demonstrated its applicability in a number of studies on DOM molecular compositions (Hertkorn et al. 2008; Nebbioso and Piccolo 2013; Schmidt et al. 2011). These studies take into account thousands of molecular components of DOM. Further data analysis allows understanding what presence/absence (or changes in relative biomarker contribution) of different markers reflect on the biogeochemical level. Previous studies demonstrated that the application of statistical tools simplifies data interpretation (Koch et al. 2008; Kujawinski et al. 2009; Sleighter et al. 2010). Recent FT-ICR MS studies on Arctic DOM observed latitude and $\mathrm{pH}$ driven trends in the molecular composition of DOM in the Yenisey River (Roth et al. 2013). The authors showed that the climatic gradients along the latitude (from south to north) were related to a higher abundance of low molecular weight components, nitrogen-containing components and an increase in the degree of unsaturation of riverine DOM. For boreal lakes of Sweden it was demonstrated that parameters such as precipitation, water residence time and mean annual temperature are reflected in the DOM composition and its chemodiversity (Kellerman et al. 2014). In Arctic fjords, FT-ICR MS indicated the rapid turnover of DOM (Osterholz et al. 2014).

The aims of this research were to quantify DOC and TDN concentrations in different waters of the Lena Delta and to identify source-specific molecular markers of DOM and their relative contribution to the Lena River, melt water creeks and Buor-Khaya Bay DOM samples for an advanced understanding of DOM compositional changes in the permafrost dominated riverine region. The broad molecular view derived by FT-ICR MS is expected to expand our current knowledge about the processes involving DOM in the Lena Delta.

\section{Materials and methods}

The field sampling campaign took place in August 2009 in the Lena Delta. The highest mean air temperatures in this region occur in July $\left(10.1^{\circ} \mathrm{C}\right)$ and August $\left(8.5^{\circ} \mathrm{C}\right)$ (Boike et al. 2013). Several DOM sources were sampled including Lena River channels, 


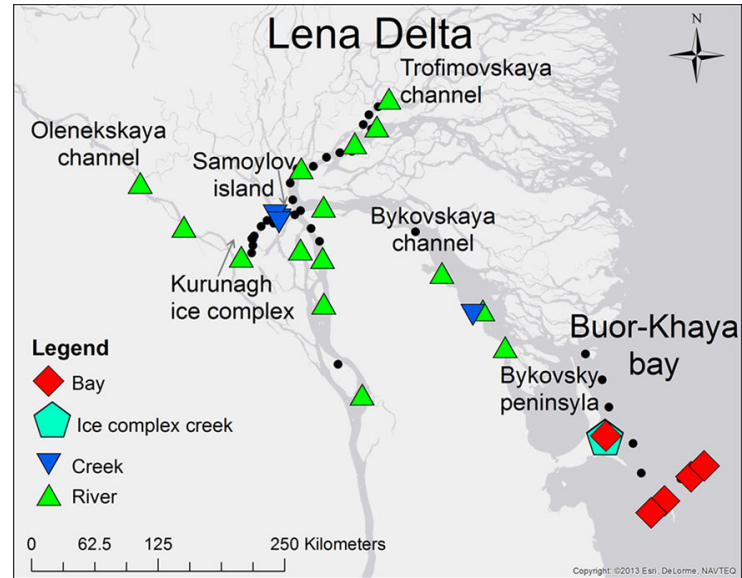

Fig. 1 Lena Delta $\left(73^{\circ} 0^{\prime} \mathrm{N}, 127^{\circ} 0^{\prime} \mathrm{E}\right)$ and sampling stations of the 2009 campaign. Riverine samples (triangles), bay samples (diamonds), permafrost creek samples (upside down triangles), ice complex melt water creeks (pentagons) and water samples used only for DOC and TDN analyses (dots)

permafrost melt water creeks (including ice complex creeks), a permafrost lake and the Buor-Khaya Bay, Laptev Sea (Fig. 1). The majority of melt water creeks and lakes were sampled on Samoylov Island. Creeks and lakes were connected and represented different parts of the Samoylov Island system. Ice complex melt water creeks derived from the ice complex on the Bykovsky Peninsula. All samples except the bay were fresh waters. In the bay the range of salinity varied from 0 to 2 .

Water was sampled from different depths using a Niskin water sampler or pre-cleaned glass bottles for creek sampling. Samples were filtered through $0.7 \mu \mathrm{m}$ $\mathrm{GF} / \mathrm{F}$ filters (Whatman, pre-combusted, $4 \mathrm{~h}, 450{ }^{\circ} \mathrm{C}$ ). DOC and total dissolved nitrogen (TDN) concentrations were measured using high temperature catalytic oxidation (TOC-VCPN, Shimadzu). Water samples were acidified in the auto sampler to remove inorganic carbon and analyzed directly.

DOM samples were concentrated directly in the field using pre-packed solid phase extraction (SPE) cartridges (PPL, Varian). SPE was applied for enrichment and purification (i.e., removal of inorganic constituents). After extraction, the cartridges were dried with nitrogen and stored at $-20{ }^{\circ} \mathrm{C}$. Back in the lab, the cartridges were eluted with methanol (Lichrosolv, Merck). The DOC content of SPE-DOM was determined by evaporation of $50 \mu \mathrm{l}$ methanol extract and re-dissolved in ultra-pure water. Details of the method are described in (Dittmar et al. 2008). The extraction efficiency varied from 30 to $60 \%$.

Fourier transform ion cyclotron resonance mass spectrometry

Ultra-high resolution mass spectra for 31 Lena Delta DOM samples were acquired in one batch on a Bruker Apex 12 Qe FT-ICR MS equipped with a 12T superconducting magnet and an APOLLO II electrospray source. SPE-DOM methanol extracts were adjusted to $\sim 200 \mu \mathrm{mol} \mathrm{C} \mathrm{L}{ }^{-1}$ DOC concentrations by dilution with methanol/water (1:1). Samples were analyzed with electrospray ionization (ESI) in negative ionization mode. The average FT-ICR mass spectrum was composed of 512 consecutive scans. The spectra were recalibrated internally by characteristic DOM ions $\left(\left[\mathrm{C}_{16} \mathrm{H}_{19} \mathrm{O}_{8}\right]^{-}-339.10854 \mathrm{~m} / \mathrm{z} ;\left[\mathrm{C}_{17} \mathrm{H}_{21} \mathrm{O}_{9}\right]^{-}-369.11911 \mathrm{~m} / \mathrm{z}\right.$; $\left[\mathrm{C}_{19} \mathrm{H}_{23} \mathrm{O}_{10}\right]^{-}-411.12967 \mathrm{~m} / \mathrm{z} ;\left[\mathrm{C}_{21} \mathrm{H}_{25} \mathrm{O}_{12}\right]^{-}-469$. $13515 \mathrm{~m} / \mathrm{z} ;\left[\mathrm{C}_{24} \mathrm{H}_{29} \mathrm{O}_{14}\right]^{-}-541.15628 \mathrm{~m} / \mathrm{z} ;\left[\mathrm{C}_{28} \mathrm{H}_{35}\right.$ $\left.\mathrm{O}_{14}\right]^{-}-595.20323 \mathrm{~m} / \mathrm{z} ;\left[\mathrm{C}_{28} \mathrm{H}_{35} \mathrm{O}_{15}\right]^{-}-611.19814 \mathrm{~m} /$ $\mathrm{z} ;\left[\mathrm{C}_{31} \mathrm{H}_{39} \mathrm{O}_{15}\right]^{-}-651.22944 \mathrm{~m} / \mathrm{z} ;\left[\mathrm{C}_{33} \mathrm{H}_{41} \mathrm{O}_{16}\right]^{-}-$ $693.24001 \mathrm{~m} / \mathrm{z}$ ). All ions were singly charged.

FT-ICR MS data was evaluated in the mass range of 200-500 m/z. Molecular formulas were assigned for peaks with a signal to noise ratio of more than 4 and a mass accuracy window of $\pm 0.5 \mathrm{ppm}$ (Koch et al. $2007,2005)$ and included following isotopes: ${ }^{12} \mathrm{C}(0-$ $\infty),{ }^{13} \mathrm{C}(0-1),{ }^{1} \mathrm{H}(0-\infty),{ }^{16} \mathrm{O}(0-\infty),{ }^{14} \mathrm{~N}(0-2),{ }^{32} \mathrm{~S}$ $(0-1)$. The nitrogen rule was applied and thresholds for elemental ratios were: $\mathrm{O} / \mathrm{C} \leq 1.2, \mathrm{H} / \mathrm{C} \leq 2 \mathrm{C}+$ $2+\mathrm{N}$ (Koch et al. 2005). ${ }^{13} \mathrm{C}$ isotopes were used for quality control (verification of the parent ion) but removed from the final dataset. FT-ICR MS provided exact masses of singly charged ions which allowed calculations of corresponding molecular formulas. It is important to note that each molecular formula can represent a number of isomers (Hertkorn et al. 2008). In this article, for the ease of readability, we generally refer to molecular formulas as "compounds", "components", "markers" or "constituents". We assigned $\sim 55 \%$ of peaks within the chosen thresholds. The number of assigned formulas (excluding ${ }^{13} \mathrm{C}$ isotopes) varied from 2,737 to 3,601 .

FT-ICR MS data exploration and analysis

The peak magnitudes were normalized to the sum of intensities of all identified molecular formulas of the 
molecular mass region. Peak magnitude weightedaverage elemental ratios $\mathrm{O} / \mathrm{C}_{\mathrm{wa}}, \mathrm{H} / \mathrm{C}_{\mathrm{wa}}, \mathrm{C} / \mathrm{N}_{\text {wa }}$, double bond equivalents (DBE) and mass defects were calculated from the assigned formulas. Magnitude weighted parameters $\mathrm{X}_{\mathrm{wa}}$ were calculated according to $X_{w a}=\sum_{i=1}^{n} X_{i} * M_{i} / \sum_{i=1}^{n} M_{i}$ where $\mathrm{X}$ is e.g., $\mathrm{O} / \mathrm{C}, \mathrm{H} / \mathrm{C}$ or $\mathrm{C} / \mathrm{N}, i$ is the individual molecular formula and $\mathrm{M}$ is the relative mass peak intensity (Sleighter et al. 2010). We prepared a data matrix for samples with molecular formulas as parameters where the peak magnitude corresponded to a parameter value. This data matrix was used for hierarchical clustering, principal component analysis (PCA) and indicator value analysis. For the statistical data processing, we only considered formulas, which were observed at least in five samples. By this, we avoided differences between samples, which resulted from discrete signal to noise threshold and FT-ICR MS signal fluctuation and tried to avoid false formula assignments. Molecular components revealed by FT-ICR MS were visualized using van Krevelen diagrams as ratios of elements: $\mathrm{O} / \mathrm{C}$ and H/C (van Krevelen 1950).

Cluster analysis was based on Bray-Curtis similarity (Bray and Curtis 1957) and performed using commercial software (PRIMER v.6; PRIMER-E Ltd, UK). For principal component analysis (PCA, "Chemometrics" package, R) we used a similar approach as described in Sleighter et al. 2010.

Indicator value analysis was performed according to a previous approach (Dufrene and Legendre 1997). We used molecular peaks (assigned formulas) as species and the relative intensity of peaks as species abundance. We renormalized peak intensities in each sample to a lowest intensity and rounded obtained values to integer values. By this, we mimic species counts and minimum "specie" value in each sample was 1 compare (Kellerman et al. 2014). For the indicator value analysis we used R ("labdsv" package).

\section{Results}

Dissolved organic carbon and total dissolved nitrogen

The average DOC concentrations were $492 \pm$ $79 \mu \mathrm{mol} \mathrm{C} \mathrm{L}{ }^{-1}$ for river water, $484 \pm 55 \mu \mathrm{mol} \mathrm{C} \mathrm{L}^{-1}$ for bay samples and $399 \pm 115 \mu \mathrm{mol} \mathrm{C} \mathrm{L} \mathrm{L}^{-1}$ for permafrost melt water creeks. Ice complex influenced samples from the Olenekskaya channel west of the Kurunagh showed higher DOC concentrations $\left(657 \pm 8 \mu \mathrm{mol} \mathrm{C} \mathrm{L}{ }^{-1}\right)$ compared to the riverine samples. It is, however, difficult to test the statistical significance because of the small number of Olenekskaya channel samples $(n=4)$ compared to riverine samples $(\mathrm{n}=51)$. The average TDN concentrations were $13.1 \pm 2.8 \mu \mathrm{mol} \mathrm{N} \mathrm{L}{ }^{-1}$ for river, $13.7 \pm$ $1.7 \mu \mathrm{mol} \mathrm{N} \mathrm{L}^{-1}$ for bay samples, and $19.7 \pm 7.1$ $\mu \mathrm{mol} \mathrm{N} \mathrm{L}{ }^{-1}$ for permafrost melt waters. DOC and TDN in ice complex melt water creeks were highly variable but also showed the highest concentrations of the whole Lena Delta system reaching average values of $3,910 \pm 1,780 \mu \mathrm{mol} \mathrm{C} \mathrm{L}{ }^{-1}$ and $220 \pm 138 \mu \mathrm{mol} \mathrm{N} \mathrm{L}^{-1}$, respectively. DOC/DON molar elemental ratios of the SPE-extracts, which do not contain inorganic nitrogen, were $63 \pm 17$ for riverine samples, $56 \pm 14$ for bay samples, $35 \pm 11$ for permafrost melt waters and $33 \pm 4$ for ice complex samples (complete DOC and TDN data available online: http://dx.doi.org/10. 1594/PANGAEA.831765; average DOC and TDN values available in supplementary information (SI) in Table SI-1 and Fig. SI-1).

\section{Molecular characterization of Lena Delta DOM}

FT-ICR MS characterization resulted in typical monomodal peak magnitude distributions for all DOM spectra (Fig. 2).

The typical peak distribution spanned a mass range from 200 (lower limit of the mass detector) to $600 \mathrm{~m} / \mathrm{z}$ (Fig. 2). We identified, on average, 3,100 formulas (excluding ${ }^{13} \mathrm{C}$ isotopologues) in each sample (detailed information in Table SI-2). The molecular patterns on single nominal masses revealed pronounced molecular differences between samples from the Buor-Khaya Bay, melt water creeks and Lena River (Fig. 2b-d). Particular differences were found in the relative peak magnitude of nitrogen containing mass peaks (e.g., $\left[\mathrm{C}_{17} \mathrm{H}_{20} \mathrm{~N}_{1} \mathrm{O}_{10}\right]^{-},\left[\mathrm{C}_{18} \mathrm{H}_{24} \mathrm{~N}_{1} \mathrm{O}_{9}\right]^{-}$, $\left[\mathrm{C}_{19} \mathrm{H}_{28} \mathrm{~N}_{1} \mathrm{O}_{8}\right]^{-}$). The highest relative magnitudes of nitrogenous peaks were characteristic for the permafrost melt water creek samples, the lowest for the Buor-Khaya Bay samples.

Molecular differences between samples were reflected in their peak magnitude weighted average 


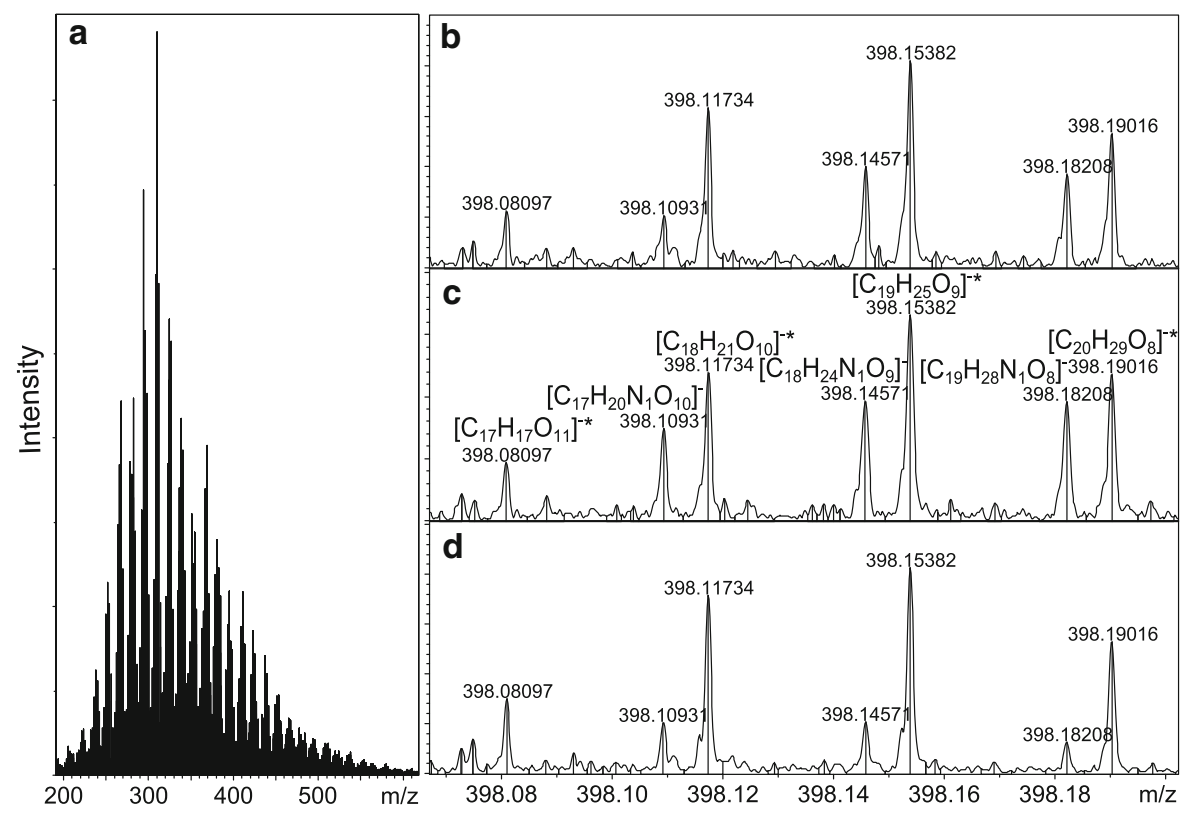

Fig. 2 Characteristic ESI negative FT-ICR mass spectrum for Lena Delta DOM with a mass range of $200-600 \mathrm{~m} / \mathrm{z}$, b mass spectrum at nominal mass 398 for a typical Lena River sample,

elemental ratios. Compared to the weighted average $\mathrm{H} / \mathrm{C}$ and $\mathrm{O} / \mathrm{C}$ ratios for riverine samples $(1.281 \pm$ 0.013 and $0.425 \pm 0.006$, respectively), Buor-Khaya Bay samples showed lower weighted average H/C ratios ranging from 1.217 to 1.241 (mean $1.230 \pm$ 0.009 ), and higher $\mathrm{O} / \mathrm{C}$ ratios of $0.445 \pm 0.002$. For the permafrost melt water creek/lake DOM, the $\mathrm{O} / \mathrm{C}$ and $\mathrm{H} / \mathrm{C}$ ratios were $0.427 \pm 0.007$ and $1.315 \pm 0.013$, respectively. DOM in ice complex melt water creeks was more oxidized than in the other creek samples. Weighted average $\mathrm{O} / \mathrm{C}$ and $\mathrm{H} / \mathrm{C}$ ratios in the ice complex DOM samples were $0.445 \pm 0.007$ and $1.268 \pm 0.024$, respectively. Highest magnitude weighted average $\mathrm{C} / \mathrm{N}$ ratios were observed for the bay samples $(\mathrm{C} / \mathrm{N}: 176 \pm 23)$ followed by the riverine $(\mathrm{C} / \mathrm{N}: 143 \pm 17)$ and creek/lake samples $(\mathrm{C} / \mathrm{N}: 104 \pm$ 15). Detailed information on weighted average elemental ratios are available in Table SI-3 and Fig. SI-2.

Molecular fingerprints

Hierarchical cluster analysis yielded four major clusters which clearly corresponded to the sample origin (Fig. 3): Lena River, Buor-Khaya Bay, permafrost creeks (including the lake sample) and ice complex c melt water creek sample, and d Buor-Khaya Bay sample. Asterisks indicate the presence of one ${ }^{13} \mathrm{C}$ isotope in the assigned formula

creeks. Samples derived from the Bykovsky Peninsula melt water creeks (ice complex samples 76 and 77) were most dissimilar from all other samples and formed a separate cluster. Samples from the same station in the river but from different depths (samples 14/15 and 12/13) showed a highly similar molecular composition (Bray-Curtis similarity $>95$ ). Although samples showed a high degree of similarity (Van Krevelen diagrams, Fig. 3), it was still possible to differentiate sources based on the molecular formula information.

To elucidate the molecular differences we calculated the average relative peak magnitude for each sample type identified by the cluster analysis. The average results for each formula containing $\mathrm{C}, \mathrm{H}, \mathrm{O}$ and $\mathrm{N}$ were presented as their elemental $\mathrm{H} / \mathrm{C}$ and $\mathrm{O} / \mathrm{C}$ ratios in the van Krevelen diagrams (Fig. 3). For the determination of those formulas which were responsible for the sample variability in the cluster analysis, we applied principal component analysis (PCA) for the same data matrix (Fig. 4).

The PCA highlighted the molecular differences of the various sample types. In total, $56.7 \%$ of variance could be explained by the first two principal components (PC, Fig. 4). PC1 and PC2 explained 31.5 and $25.2 \%$ of the variance, respectively. Since PC3 
Fig. 3 Hierarchical cluster analysis (Bray-Curtis similarity) and van Krevelen diagrams for "average samples". Molecular differences were observed between a ice complex melt water creeks (pentagons, $\mathrm{n}=2$ ), creek (triangles, $\mathrm{n}=4$ ) plus lake samples (square, $\mathrm{n}=1$ ), BuorKhaya Bay samples (diamonds, $\mathrm{n}=6$ ) and Lena River samples (green triangles, $\mathrm{n}=18$ ). For each sample type, all identified molecular formulas containing $\mathrm{C}, \mathrm{H}, \mathrm{O}$ and $\mathrm{N}$ are represented by their molecular $\mathrm{H} / \mathrm{C}$ and $\mathrm{O} / \mathrm{C}$ ratio (van Krevelen diagram). The color code represents the average relative peak magnitude

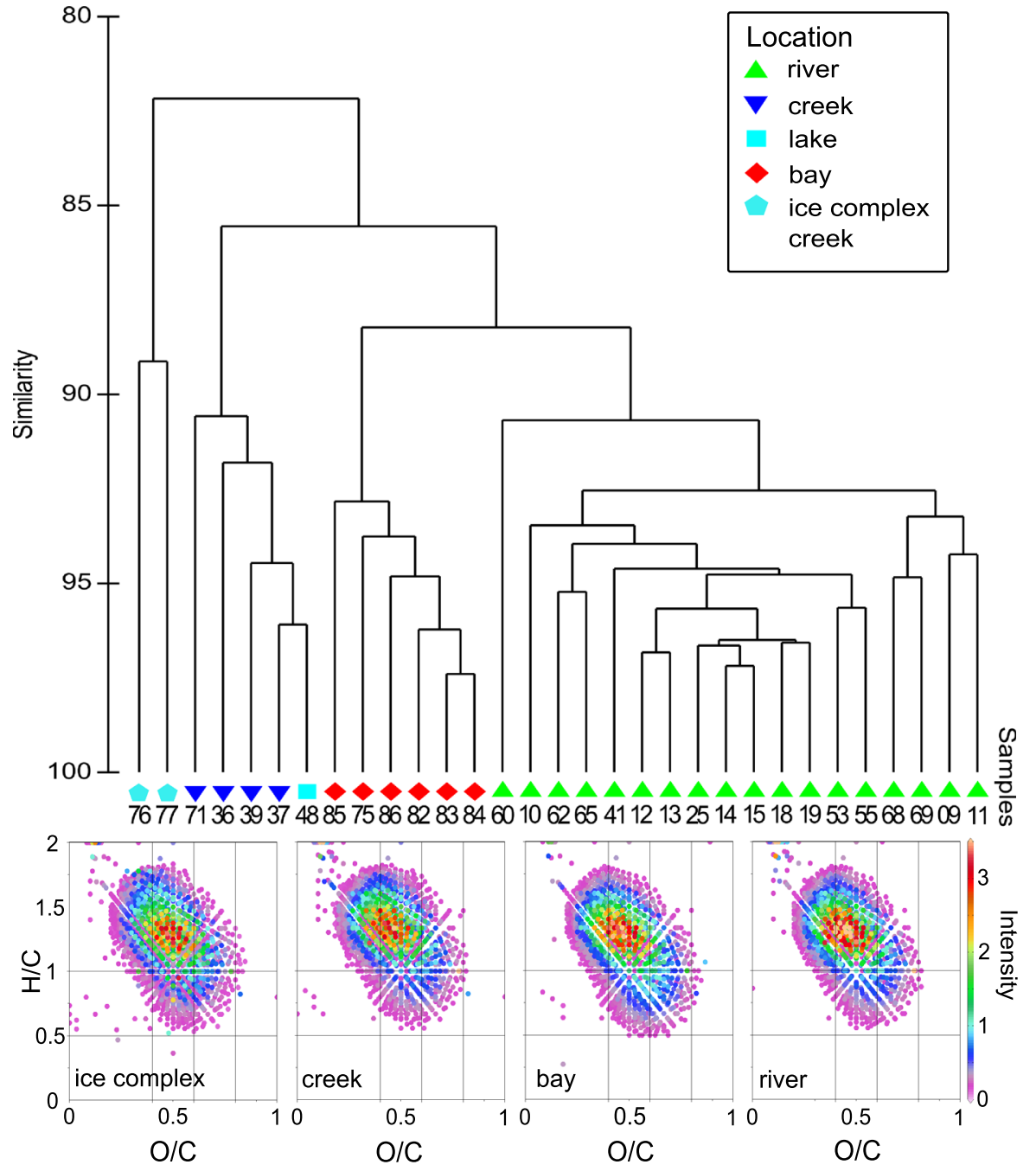

explained only $9 \%$, only the first two principal components were used for the data interpretation. Bour-Khaya Bay and permafrost melt water creeks were primarily separated on the PC1 axis whereas riverine samples showed exclusively negative PC2 values. The only exception which also showed negative PC2 values was the creek sample (sample 36) which was collected near the research station on Samoylov Island.

To identify specific molecular DOM markers for each source of DOM, the molecular formulas with the highest absolute PCA loadings for PC1 and PC2 were analyzed (Fig. 4). The combined loadings were irregularly distributed; some regions had a higher and others a lower density of data points. The majority of $\mathrm{C}_{x} \mathrm{H}_{\mathrm{y}} \mathrm{O}_{z}$ identifications showed negative loadings of $\mathrm{PC} 1$ whereas nitrogenous compounds $\left(\mathrm{C}_{\mathrm{x}} \mathrm{H}_{\mathrm{y}} \mathrm{O}_{\mathrm{z}} \mathrm{N}_{1}\right.$ and
$\mathrm{C}_{\mathrm{x}} \mathrm{H}_{\mathrm{y}} \mathrm{O}_{\mathrm{z}} \mathrm{N}_{2}$ ) had positive PC1 loadings. Therefore, $\mathrm{C}_{\mathrm{x}} \mathrm{H}_{\mathrm{y}} \mathrm{O}_{\mathrm{z}} \mathrm{N}_{1-2}$ had a higher contribution to sample variance as compared to $\mathrm{C}_{\mathrm{x}} \mathrm{H}_{\mathrm{y}} \mathrm{O}_{\mathrm{z}}$. Sulfur containing compounds did not contribute considerably to the sample variability. Additionally, negative PC1 loadings were characteristic for identifications with the highest molecular masses. For the identification and generalization of molecular drivers responsible for the sample groupings and to understand the nature of molecular differences and transformations of DOM the 500 highest positive/negative eigenvalues for each principal component were used and plotted in van Krevelen diagrams (Fig. 5).

The Buor-Khaya Bay samples (negative PC1 values, Fig. 4) showed a predominance of oxygen-rich components and nitrogenous compounds were almost 


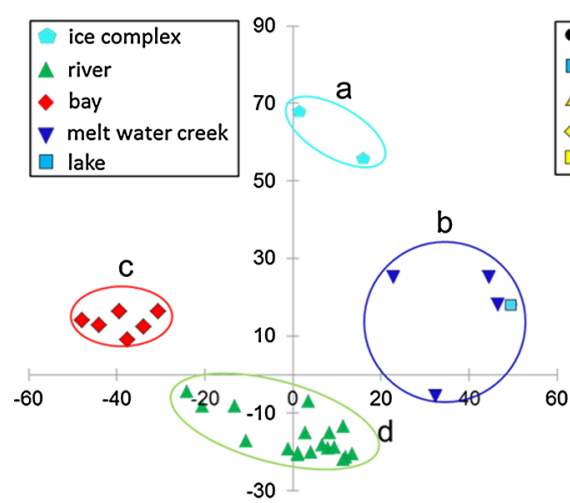

Fig. 4 Principal component analysis. PC1 and PC2 explained $56.7 \%$ of the variance in the biplot (left panel): a ice complex creek DOM samples (pentagons), b permafrost creeks and lake DOM samples (upside down triangles and square), c BuorKhaya Bay samples (diamonds), d Lena River DOM samples

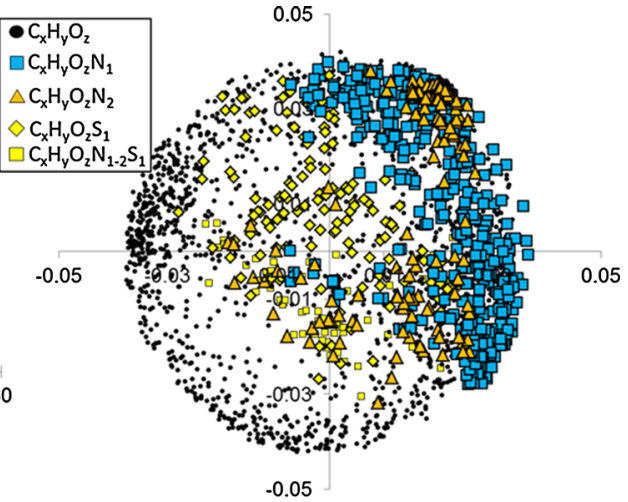

(triangles). The PCA loadings highlighted the molecular formulas with respect to nitrogen and sulfur content (right panel): no nitrogen and sulfur (circles), one nitrogen atom (squares), two nitrogen atoms (triangles), one sulfur (light diamonds), sulfur and nitrogen (light squares)
Fig. 5 Van Krevelen plots for the 500 highest positive/ negative PC loadings: a 500 positive eigenvalues for PC1, b 500 negative for $\mathrm{PC} 1$, c 500 positive $\mathrm{PC} 2$, d 500 negative for $\mathrm{PC} 2$. $\mathrm{C}_{\mathrm{x}} \mathrm{H}_{\mathrm{y}} \mathrm{O}_{\mathrm{z}}$ molecular formulas (circles) were distinguished from $\mathrm{C}_{\mathrm{x}} \mathrm{H}_{\mathrm{y}} \mathrm{O}_{\mathrm{z}} \mathrm{N}_{1}$ (squares), $\mathrm{C}_{\mathrm{x}} \mathrm{H}_{\mathrm{y}} \mathrm{O}_{\mathrm{z}} \mathrm{N}_{2}$ (triangles), $\mathrm{C}_{\mathrm{x}} \mathrm{H}_{\mathrm{y}} \mathrm{O}_{\mathrm{z}} \mathrm{S}_{1}$ (light diamonds), and $\mathrm{C}_{\mathrm{x}} \mathrm{H}_{\mathrm{y}} \mathrm{O}_{\mathrm{z}} \mathrm{N}_{1-2} \mathrm{~S}_{1}$ (light squares). (Color figure online)

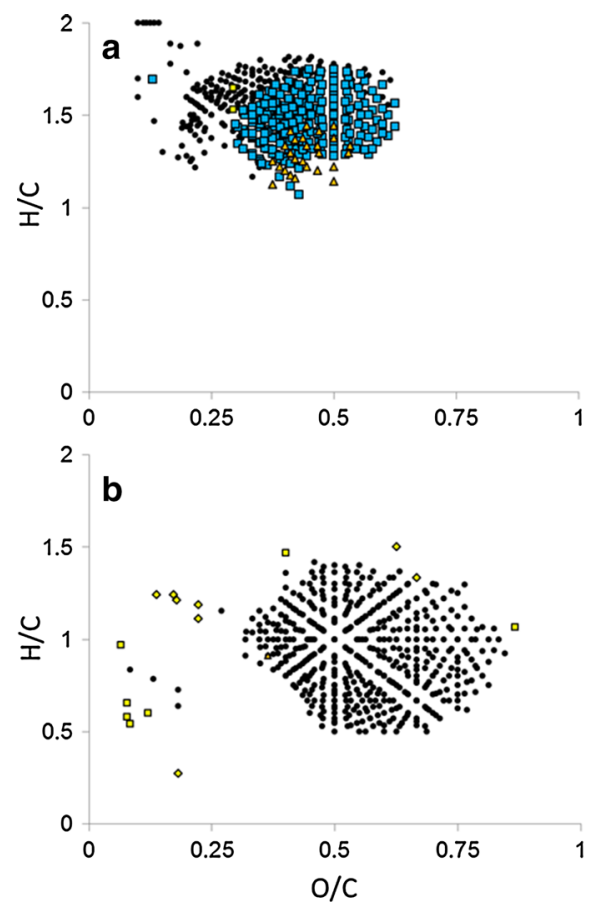

absent in formulas which showed negative PC1 loadings (Fig. 5b). Formulas with high positive PC1 loadings contained many $\mathrm{N}$-containing formulas (Figs. 4, 5a). The clear separation of compounds with positive and negative PC1 loadings in the van Krevelen diagrams particularly reflected the differences in chemical compositions and properties and the relation to sample origin.

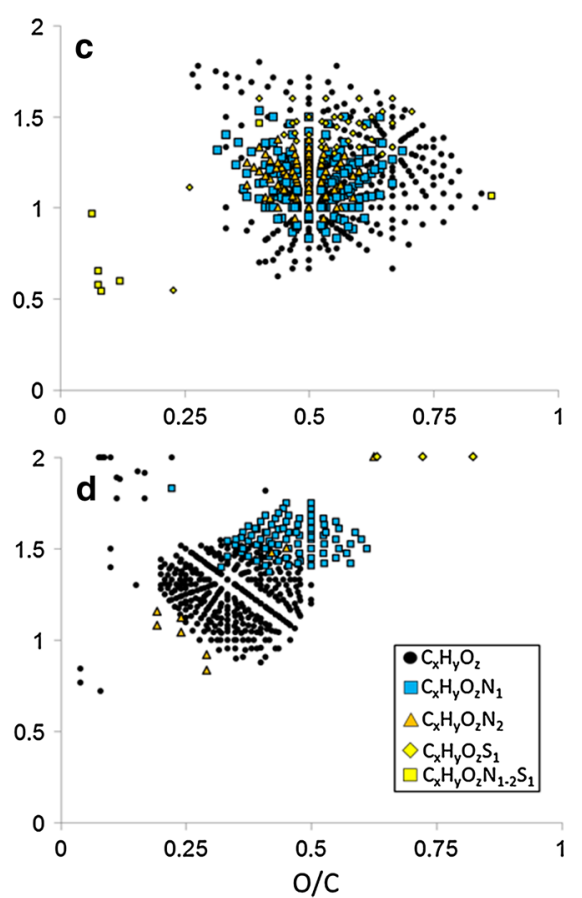

High PC2 values were characteristic for bay and creek water samples with the highest values for ice complex creek samples. The $\mathrm{C}_{\mathrm{x}} \mathrm{H}_{\mathrm{y}} \mathrm{O}_{\mathrm{z}}$ identifications with the highest $\mathrm{PC} 2$ loadings had high $\mathrm{O} / \mathrm{C}$ ratios, but were more hydrogen saturated compared to the lowest PC1 loadings. There was also a core of nitrogenous compounds with the "center of mass" at $\mathrm{O} / \mathrm{C} \sim 0.55$ and $\mathrm{H} / \mathrm{C} \sim 1.2$ (Fig. $5 \mathrm{c}$ ). The contribution of 
molecular formulas with low PC2 scores to the bay sample variability was minor and formulas with high positive PC2 loadings did not explain variance in the bay samples. Molecular components with negative PC2 loadings (Fig. 5d) mostly represent riverinedominant DOM molecular formulas. We have visualized molecular transformation trends on the upstreamdownstream transect. This information with applied procedures is available in the supplementary materials.

Indicator peaks supported the sample groups (permafrost melt water creeks, ice complex creeks, river and bay samples) assigned in the cluster analysis (Fig. 6). Using only significant indicator values ( $<<0.05$; Fig. 6), bay samples had high $\mathrm{O} / \mathrm{C}$ ratios and a relatively high degree of unsaturation in comparison to ice complex, creek and river DOM samples. Creek DOM samples had highly aliphatic indicator molecular markers. Riverine indicator markers took an intermediate position between the bay and creek DOM samples (Fig. 6). It is difficult to judge representativeness of the indicators of ice complex creek DOM due to the low number of samples $(\mathrm{n}=2)$. Using the available data, riverine indicators (Fig. 6) match well with the PCA loadings (negative PC2 values; Fig. 5d). Therefore, river-dominant DOM compounds exposed a relative depletion of oxygen $(\mathrm{O} / \mathrm{C}$ ranged from 0.25 to 0.5$)$ and high $\mathrm{H} / \mathrm{C}$ ratios (ranging from 1 to 1.55; (Fig. 6, Figs. SI-4/5 and Table SI-4)).

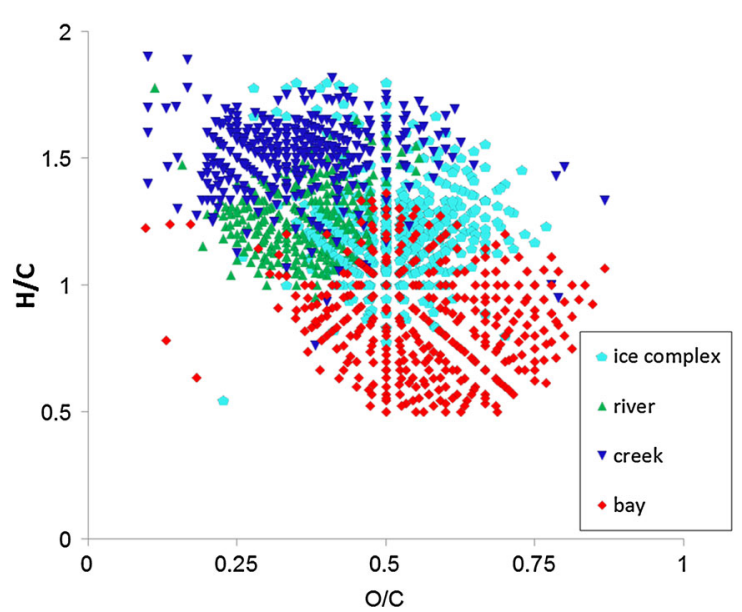

Fig. 6 Van Krevelen diagrams with indicator peaks determined by indicator value analysis (indicator values of Dufrêne and Legendre)
DOM classification

Based on the information derived from the PCA, the individual formulas were examined in more detail. The series of formulas which solely contained $\mathrm{C}, \mathrm{H}$, and $\mathrm{O}$ (Fig. 5a) revealed that compounds with higher numbers of oxygen clearly prevailed in the bay samples. This observation fit well with the prevalent oxygenated formulas in the bay samples (Fig. 5b). The classes $\mathrm{O}_{1}-\mathrm{O}_{6}$ of the bay samples had the lowest number of identifications compared with the riverine and creek samples. However, in the compound classes with $>5$ oxygen atoms, the bay samples showed the highest number of oxygen-rich identifications (Fig. 7).

Compounds containing one nitrogen atom were predominantly detected in river and creek samples (Fig. 6b and Fig. 7). The lowest abundance of this compound class was observed for the bay samples. A similar trend was found for compounds containing two nitrogen atoms. These results agreed well with the PCA loadings.

\section{Discussion}

Little is known about the role, dynamics and transformation of DOM in the Arctic ecosystem in particular with regard to permafrost, its thawing and predicted changes due to global warming. The average DOC concentration of about $500 \mu \mathrm{mol} \mathrm{C} \mathrm{L}{ }^{-1}$ and TDN concentration of $13 \mu \mathrm{mol} \mathrm{N} \mathrm{L}{ }^{-1}$ in the Lena River in the summer 2009 were similar to values presented in previous studies (Lara et al. 1998; Lobbes et al. 2000). DON concentrations in the summer months are the highest within the seasons (Holmes et al. 2012), potentially because of the high number of very different DOM sources with less degraded material. Highest DOC concentrations are characteristic for the freshet period. Elevated DON values in late summer represent a source shift of organic matter in the river, likely because of increasing contribution of permafrost organic matter. Freshet periods are characterized by a large contribution of organic matter from surface layers of soils (Finlay et al. 2006). In late summer, the contribution of surface soil layer DOM decreases and the contribution of deeper soil horizons increases. An increase of soil derived organic matter in the permafrost influenced Kolyma River was inferred from the changes in the radiocarbon age of DOC in late summer (Neff et al. 2006). Since it 
Fig. 7 a Classification of $\mathrm{C}_{\mathrm{x}} \mathrm{H}_{\mathrm{y}} \mathrm{O}_{\mathrm{z}}$ identified molecular formulas based on the number of oxygen atoms per identification.

b Classification of $\mathrm{C}_{\mathrm{x}} \mathrm{H}_{\mathrm{y}} \mathrm{O}_{\mathrm{z}} \mathrm{N}_{1}$ identified molecular formulas based on the number of oxygen atoms per identification

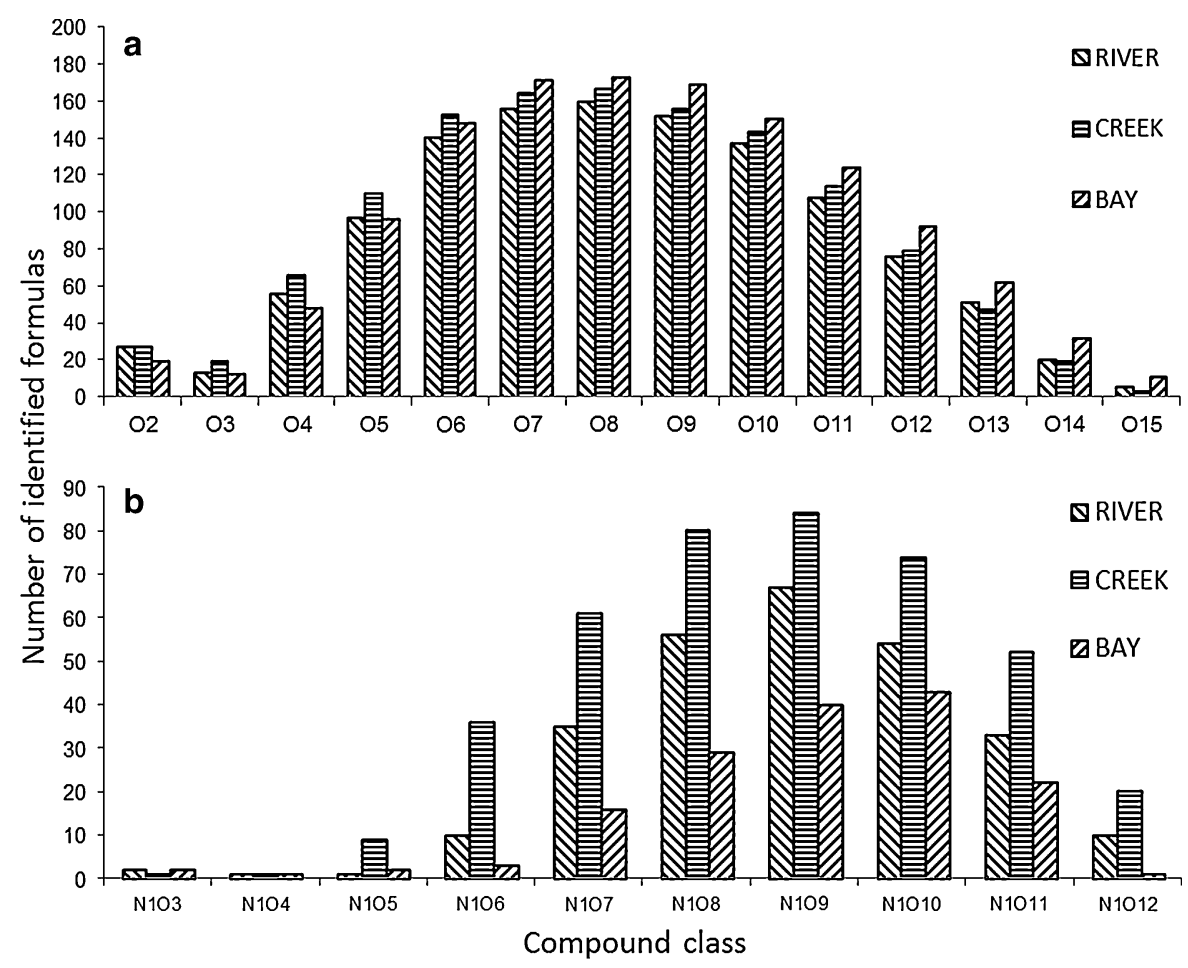

was demonstrated that organic matter released by permafrost degradation could be more labile, this organic matter will affect regional microbial activity and primary production in the Lena River and the inner Laptev Sea. Decomposition of about $34 \%$ of DOC was characteristic for Yedoma (ice complex) melt water streams and of 17-33\% for river-creek water mixtures (Vonk et al. 2013). We did not observe that DOC concentrations increased continuously on the way from the most upstream to the downstream sample. Thus, deltaic permafrost emitted DOM obviously did not affect riverine DOC concentration probably due to high mineralization rates and dilution by the huge river water volume.

DOC and TDN values for ice complex melt waters were extremely high. Several melt water creeks with very high DOC concentrations drain the massive ice complex on Kurunagh Island and discharge into the Olenekskaya channel. These DOM pulses probably caused the elevated DOC concentration in the channel $\left(660 \mu \mathrm{mol} \mathrm{C} \mathrm{L}{ }^{-1}\right)$. Since the Olenekskaya channel discharges only $\sim 6.5 \%$ as compared to the total Lena River water (Fedorova et al. 2013) ice complex derived DOC contributes only very little to river DOC in the entire Lena Delta. The few ice complexes are sporadically distributed (Are and Reimnitz 2000). They are syngenetically frozen, fine-grained deposits and are built of large amounts of ground ice and massive ice wedges. The ice complexes also contain considerable amounts of fossil organic carbon that might become accessible due to permafrost thawing (Khvorostyanov et al. 2008; Schirrmeister et al. 2011) but it is unknown if this material is labile or refractory.

DOC and TDN concentrations in permafrost melt waters were highly variable and $\sim 10$ times lower than in the ice complex derived water. In contrast to the river and bay, the DOC concentrations of the melt water creeks were more variable and were slightly lower in DOC and higher in TDN. Permafrost melt waters are exposed to more environmental factors in comparison with the river. The influence of vegetation type, intense exposure to the light, different contributions of active organic matter layers and nutrients are more pronounced (Rodionov et al. 2007). Also, mixing processes, which are intense in the river, might be less important in the creeks resulting in a higher DOC and TDN variability.

Molar $\mathrm{C} / \mathrm{N}$ ratios of DOM and SPE-DOM were different but the trends were similar. Inorganic nitrogenous nutrients are almost negligible in summer 
(Holmes et al. 2012; Lobbes et al. 2000) and thus DON is only slightly lower than TDN determined in our study. SPE-DOM contains only traces of inorganic material, and therefore TDN concentrations were equivalent to $\mathrm{DON}$. The $\mathrm{C} / \mathrm{N}$ ratios did not allow discrimination of riverine and bay samples, although ratios were slightly lower in the bay samples which however were still mostly dominated by Lena River water with almost no salinity. The high $\mathrm{C} / \mathrm{N}$ ratios are typical for the Arctic rivers (e.g., Lobbes et al. 2000) decreasing by a factor of two in the open Laptev Sea (Kattner et al. 1999). DOM of riverine and bay samples were reduced in DON compared to the creeks. The $\mathrm{C} / \mathrm{N}$ ratios of this ice complex runoff $(\sim 33)$ reflect a high contribution of relatively fresh material released by the thawing process. This is further evidence for the lability and degradability of organic matter deposited in permafrost. The DOM may also originate from thawing of long-term frozen particulate material. In contrast, the particulate material in the Lena River is mostly allochthonous, soil-derived organic matter accumulated along the enormous length of the river. Autochthonous production is low because of the nutrient limitation and the high turbidity.

The obvious and interesting changes in the relative nitrogen content of the samples were reflected in the FT-ICR MS analyses. This supports the observations derived from bulk DOC and TDN measurements that during the transport of DOM from the thawing permafrost into the melt water creeks and the river and finally the Buor-Khaya Bay a continuous decline of nitrogen containing molecules occurred (Figs. 4,7). The N-containing formulas in Fig. 5a (those enriched in the permafrost creeks and lake DOM) are mostly aliphatic (based on their $\mathrm{H} / \mathrm{C}$ ratios) and could likely be related to peptide-like moieties (based on their $\mathrm{O} / \mathrm{C}$ ratio). Although FT-ICR MS is a semi-quantitative method, it clearly demonstrated the relative depletion of nitrogenous compounds in the bay samples. The $\mathrm{O} / \mathrm{C}_{\mathrm{wa}}, \mathrm{H} / \mathrm{C}_{\mathrm{wa}}$ and $\mathrm{C} / \mathrm{N}_{\mathrm{wa}}$ ratios exposed the general enrichment of creek DOM samples by nitrogenous components and vice versa in the bay samples, which were more oxidized. The clearly higher $\mathrm{C} / \mathrm{N}$ ratios calculated from the weighted average FT-ICR MS data than from the bulk data are due to the strict intensity threshold used in FT-ICR MS data processing, which excludes the low intensity nitrogenous mass peaks. Nevertheless, the trend was similar to the bulk measurements. Hierarchical clustering of the FTICR MS data showed that the origin of DOM was systematically reflected in its molecular composition also beyond the contribution of nitrogen containing compounds. Principal component analysis also highlighted the importance of nitrogenous and oxidized components for the molecular variance of DOM in the creek, river and Buor-Khaya Bay samples. Even the different types of creeks could be distinguished: permafrost melt water creeks differed from organicrich ice complex melt water creeks. Obviously, the type of permafrost also affected the composition of released DOM.

On a smaller spatial scale, as studied on Samoylov Island (samples 48, 36, 37, 39), the composition of all DOM samples was very similar. Even the molecular composition of the lake sample matched with the creek samples. Creeks on Samoylov Island drain the lakes and therefore, lake and creek DOM samples have the same origin that is the active layer of permafrost and the local vegetation. The similarity of the one single lake sample and the creeks suggests that the prevailing molecular pattern from the lake sample remained largely unaltered in the creek run-off on its short way $(<1,000 \mathrm{~m})$ to the Lena River.

The molecular changes from river to bay might be partially explained by precipitation/flocculation of less-hydrophilic molecules (Lantuit et al. 2012) although there was no pronounced salinity gradient in the bay (maximum salinity of 2). This observation opposed previous findings. For example, compositional differences of DOM presented for marine and mangrove systems (Koch et al. 2005) and for a riverocean transect in the Chesapeake Bay (Sleighter and Hatcher 2008) showed that DOM tends to become more aliphatic and depleted in oxygen-rich molecules from inshore to offshore. However, the bay samples in our study were still largely influenced by the riverine DOM and therefore did not represent marine waters. Also, it was shown that the phytoplankton communities are different in the Lena Delta and Buor-Khaya Bay due to the increasing amounts of seawater mixed to the riverine freshwater (Kraberg et al. 2013). These observations might be more important for molecular differences between river and bay samples than physico-chemical processes due to the slight salinity gradient. Open ocean studies have shown that the molecular composition of DOM differs between biological provinces (Koch and Kattner 2012). Also, 
previously it was demonstrated that DOM photodegradation resulted in production of highly oxidized organic molecules, similar to molecular components dominated in the bay samples of our study (Gonsior et al. 2013). Since summers in the Arctic are characterized with intense $24 \mathrm{~h}$ sun activity, the observable molecular characteristics of the bay samples could also be a result of riverine DOM photo-degradation.

Source-specific and source-dominant molecular markers will allow in future estimates of the various contributions to DOM which integrates signals from diverse sources (e.g., riverine and estuarine DOM). Since Lena River is affected by the climate change driven factors (discharge increase, permafrost degradation, changes in vegetation) and permafrostderived DOM believed is to be labile, quantification of its contribution to riverine DOM and analysis of its further fate is important.

\section{Conclusions}

Bulk DOM parameters matched with the DOM molecular fingerprints, especially with focus on the nitrogenous fraction. FT-ICR MS was successfully employed as a tool for non-targeted biogeochemical studies of DOM in the Lena Delta. DOM samples were clearly differentiated according to source. DOM systematic molecular characteristics with respect to water origin potentially allow understanding of processes and transformations of DOM. Origin-systematic molecular composition is originating from different mechanisms of DOM formation. Therefore, our study supports the identification of processes and environmental parameters responsible for molecular DOM fingerprints. Special attention needs to be addressed to the quantification of DON fluxes in the region.

The compositional changes could present a major direction of DOM mineralization and transformation processes in the deltaic system of the Lena River. Since DOM is an important player in the carbon cycle the advanced understanding of DOM mineralization which results in $\mathrm{CO}_{2}$ emission could provide additional knowledge on dynamics of changes in DOM. Understanding of these dynamics will allow predictions and record changes in carbon cycling. Climate change can potentially cause an increase of the active permafrost layer in the Arctic which will increasingly contribute to the amount of soil-derived organic matter in the rivers (Gustafsson et al. 2011). Since we demonstrated significant differences of the DOM molecular composition of melt water creeks and the Lena River, the growing contribution by permafrost DOM might also change the riverine biogeochemistry in the Lena Delta and the Laptev Sea with consequence on the ecosystem.

Acknowledgments We acknowledge the support of logistics department of the Alfred Wegener Institute in face of Waldemar Schneider. We thank Michail Grigoriev for his involvement and help in organizational processes during the Lena Delta 2009 expedition. We are grateful to the group of Philippe SchmittKopplin for access to FT-ICR MS facilities, their support in the sample analyses and data interpretation.

\section{References}

Abbt-Braun G, Frimmel FH (2002) Refractory organic substances in the environment. Wiley- $\mathrm{VCH}$, Cambridge

Amon RMW, Meon B (2004) The biogeochemistry of dissolved organic matter and nutrients in two large Arctic estuaries and potential implications for our understanding of the Arctic Ocean system. Mar Chem 92:311-330

Are F, Reimnitz E (2000) An overview of the Lena River Delta setting: geology, tectonics, geomorphology, and hydrology. J Coast Res 16:1083-1093

Bhatt US, Walker DA, Raynolds MK, Comiso JC, Epstein HE, Jia GS, Gens R, Pinzon JE, Tucker CJ, Tweedie CE, Webber PJ (2010) Circumpolar Arctic tundra vegetation change is linked to sea ice decline. Earth Interact 14:20

Boike J, Kattenstroth B, Abramova K, Bornemann N, Chetverova A, Fedorova I, Fröb K, Grigoriev M, Grüber M, Kutzbach L, Langer M, Minke M, Muster S, Piel K, Pfeiffer EM, Stoof G, Westermann S, Wischnewski K, Wille C, Hubberten HW (2013) Baseline characteristics of climate, permafrost, and land cover from a new permafrost observatory in the Lena River Delta, Siberia (1998-2011). Biogeosciences 10:2105-2128

Bray JR, Curtis JT (1957) An ordination of the upland forest communities of southern Wisconsin. Ecol Monogr 27: 326-349

Cooke MP, van Dongen BE, Talbot HM, Semiletov I, Shakhovaa N, Guo L, Gustadsson O (2009) Bacteriohopanepolyol biomarker composition of organic matter exported to the Arctic Ocean by seven of the major Arctic rivers. Org Geochem 40:1151-1159

Dittmar T, Kattner G (2003) The biogeochemistry of the river and shelf ecosystem of the Arctic Ocean: a review. Mar Chem 83:103-120

Dittmar T, Koch BP, Hertkorn N, Kattner G (2008) A simple and efficient method for the solid-phase extraction of dissolved organic matter (SPE-DOM) from seawater. Limnol Oceanogr Methods 6:230-235

Doxaran D, Ehn J, Belanger S, Matsuoka A, Hooker S, Babin M (2012) Optical characterisation of suspended particles in the Mackenzie River plume (Canadian Arctic Ocean) and 
implications for ocean colour remote sensing. Biogeosciences 9:3213-3229

Dufrene M, Legendre P (1997) Species assembles and indicator species: the need for a flexible asymmetrical approach. Ecol Monogr 67:345-366

Engelhaupt E (2008) Don't be fooled by seemingly “permanent" permafrost. Environ Sci Technol 42:8623-8624

Fedorova I, Chetverova A, Bolshiyanov D, Makarov A, Boike J, Heim B, Morgenstern A, Overduin P, Wegner C, Kashina V, Eulenburg A, Dobrotina E, Sidorina I (2013) Lena Delta hydrology and geochemistry. Biogeosciences Discuss 10:20179-20237

Finlay J, Neff J, Zimov S, Davydova A, Davydov S (2006) Snowmelt dominance of dissolved organic carbon in highlatitude watersheds: implications for characterization and flux of river DOC. Geophys Res Lett 33:5

Flerus R, Lechtenfeld OJ, Koch BP, McCallister SL, SchmittKopplin P, Benner R, Kaiser K, Kattner G (2012) A molecular perspective on the ageing of marine dissolved organic matter. Biogeosciences 9:1935-1955

Frey KE, McClelland JW (2009) Impacts of permafrost degradation on arctic river biogeochemistry. Hydrol Process 23:169-182

Gonsior M, Schmitt-Kopplin P, Bastviken D (2013) Depthdependent molecular composition and photo-reactivity of dissolved organic matter in a boreal lake under winter and summer conditions. Biogeosciences 10:6945-6956

Guo L, Ping CL, Macdonald RW (2007) Mobilisation pathways of organic carbon from permafrost to arctic rivers in a changing climate. Geophys Res Lett 34:L13603

Gustafsson O, van Dongen BE, Vonk JE, Dudarev OV, Semiletov IP (2011) Widespread release of old carbon across the Siberian Arctic echoed by its large rivers. Biogeosciences 8:1737-1743

Hertkorn N, Frommberger M, Witt M, Koch BP, SchmittKopplin P, Perdue EM (2008) Natural organic matter and the event horizon of mass spectrometry. Anal Chem 80:8908-8919

Holmes RM, McClelland JW, Peterson BJ, Tank SE, Bulygina E, Eglinton TI, Gordeev VV, Gurtovaya TY, Raymond PA, Repeta DJ, Staples R, Striegl RG, Zhulidov AV, Zimov SA (2012) Seasonal and annual fluxes of nutrients and organic matter from large rivers to the Arctic Ocean and surrounding seas. Estuaries Coasts 35:369-382

Jiao NZ, Herndl GJ, Hansell DA, Benner R, Kattner G, Wilhelm SW, Kirchman DL, Weinbauer MG, Luo TW, Chen F, Azam F (2011) The microbial carbon pump and the oceanic recalcitrant dissolved organic matter pool. Nat Rev Microbiol 8:593-599

Karlsson ES, Charkin A, Dudarev O, Semiletov I, Vonk JE, Sanchez-Garcia L, Andersson A, Gustafsson O (2011) Carbon isotopes and lipid biomarker investigation of sources, transport and degradation of terrestrial organic matter in the Buor-Khaya Bay, SE Laptev Sea. Biogeosciences 8:1865-1879

Kattner G, Lobbes JM, Fitznar HP, Engbrodt R, Nöthig EM, Lara RJ (1999) Tracing dissolved organic substances and nutrients from the Lena River through Laptev Sea (Arctic). Mar Chem 65:25-39

Kellerman AM, Dittmar T, Kothawala DN, Tranvik LJ (2014) Chemodiversity of dissolved organic matter in lakes driven by climate and hydrology. Nat Commun 5:3804
Khvorostyanov DV, Ciais P, Krinner G, Zimov SA (2008) Vulnerability of east Siberia's frozen carbon stores to future warming. Geophys Res Lett 35:L10703

Koch BP, Kattner G (2012) Preface "sources and rapid biogeochemical transformation of dissolved organic matter in the Atlantic surface ocean". Biogeosciences 9:2597-2602

Koch BP, Witt M, Engbrodt R, Dittmar T, Kattner G (2005) Molecular formulae of marine and terrigenous dissolved organic matter detected by electrospray ionization Fourier transform ion cyclotron resonance mass spectrometry. Geochim Cosmochim Acta 69:3299-3308

Koch BP, Dittmar T, Witt M, Kattner G (2007) Fundamentals of molecular formula assignment to ultrahigh resolution mass data of natural organic matter. Anal Chem 79:1758-1763

Koch BP, Ludwichowski K-U, Kattner G, Dittmar T, Witt M (2008) Advanced characterization of marine dissolved organic matter by combining reversed-phase liquid chromatography and FT-ICR-MS. Mar Chem 111:233-241

Kraberg AC, Druzhkova E, Heim B, Loeder MJG, Wiltshire KH (2013) Phytoplankton community structure in the Lena Delta (Siberia, Russia) in relation to hydrography. Biogeosciences 10:7263-7277

Kujawinski EB, Longnecker K, Blough NV, Del Veniccio R, Finlay L, Kitner JB, Giovannoni SJ (2009) Identification of possible source markers in marine dissolved organic matter using ultrahigh resolution mass spectrometry. Geochim Cosmochim Acta 73:4384-4399

Lantuit H, Rachold V, Pollard WH, Steenhuisen F, Odegard R, Hubberten HW (2009) Towards a calculation of organic carbon release from erosion of Arctic coasts using nonfractal coastline datasets. Mar Geol 257:1-10

Lantuit H, Overduin PP, Couture N, Wetterich S, Are F, Atkinson D, Brown J, Cherkashov G, Drozdov D, Forbes DL, Graves-Gaylord A, Grigoriev M, Hubberten HW, Jordan J, Jorgenson T, Odegard RS, Ogorodov S, Pollard WH, Rachold V, Sedenko S, Solomon S, Steenhuisen F, Streletskaya I, Vasiliev A (2012) The Arctic coastal dynamics database: a new classification scheme and statistics on Arctic permafrost coastlines. Estuaries Coasts 35:383-400

Lara RJ, Rachold V, Kattner G, Hubberten HW, Guggenberger G, Skoog A, Thomas DN (1998) Dissolved organic matter and nutrients in the Lena River, Siberian Arctic: characteristics and distribution. Mar Chem 59:301-309

Le Fouest V, Babin M, Tremblay JE (2013) The fate of riverine nutrients on Arctic shelves. Biogeosciences 10:3661-3677

Lechtenfeld OJ, Kattner G, Flerus R, McCallister SL, SchmittKopplin P, Koch BP (2014) Molecular transformation and degradation of refractory dissolved organic matter in the Atlantic and Southern Ocean. Geochim Cosmochim Acta 126:321-337

Lobbes JM, Fitznar HP, Kattner G (2000) Biogeochemical characteristics of dissolved and particulate organic matter in Russian rivers entering the Arctic Ocean. Geochim Cosmochim Acta 64:2973-2983

McClelland JW, Holmes RM, Peterson BJ, Stieglitz M (2004) Increasing river discharge in the Eurasian Arctic: consideration of dams, permafrost thaw, and fires as potential agents of change. J Geophys Res 109:D18102

Nebbioso A, Piccolo A (2013) Molecular characterization of dissolved organic matter (DOM): a critical review. Anal Bioanal Chem 405:109-124 
Neff JC, Finlay JC, Zimov SA, Davydov SP, Carrasco JJ, Schuur EAG, Davydova AI (2006) Seasonal changes in the age and structure of dissolved organic carbon in Siberian rivers and streams. Geophys Res Lett 33:L23401

Opsahl S, Benner R, Amon RMW (1999) Major flux of terrigenous dissolved organic matter through the Arctic Ocean. Limnol Oceanogr 44:2017-2023

Osterholz H, Dittmar T, Niggemann J (2014) Molecular evidence for rapid dissolved organic matter turnover in Arctic fjords. Mar Chem 160:1-10

Peterson BJ, Holmes RM, McClelland JW, Vorosmarty CJ, Shiklomanov IA, Lammers RB, Rahmstorf S (2002) Increasing river discharge to the Arctic Ocean. Science 298:2171-2173

Raymond PA, McClelland JW, Holmes RM, Zhulidov AV, Mull K, Peterson BJ, Striegl RG, Aiken GR, Gurtovaya TY (2007) Flux and age of dissolved organic carbon exported to the Arctic Ocean: a carbon isotopic study of the five largest Arctic rivers. Glob Biogeochem Cycles 21:GB4011

Rodionov A, Flessa H, Grabe M, Kazansky OA, Shibistova O, Guggenberger G (2007) Organic carbon and total nitrogen variability in permafrost-affected soils in a forest tundra ecotone. Eur J Soil Sci 58:1260-1272

Roehm CL, Giesler R, Karlsson J (2009) Bioavailability of terrestrial organic carbon to lake bacteria: the case of a degrading subarctic permafrost mire complex. J Geophys Res Biogeosciences 114:G03006

Roth VN, Dittmar T, Gaupp R, Gleixner G (2013) Latitude and $\mathrm{pH}$ driven trends in the molecular composition of DOM across a north south transect along the Yenisei River. Geochim Cosmochim Acta 123:93-105

Schirrmeister L, Grosse G, Wetterich S, Overduin PP, Strauss J, Schuur EAG, Hubberten HW (2011) Fossil organic matter characteristics in permafrost deposits of the northeast Siberian Arctic. J Geophys Res Biogeosciences 116:G00M02

Schmidt F, Koch BP, Elvert M, Schmidt G, Witt M, Hinrichs K-U (2011) Diagenetic transformation of dissolved organic nitrogen compounds under contrasting sedimentary redox conditions in the Black Sea. Environ Sci Technol 45:5223-5229

Schuur EAG, Bockheim J, Canadell JG, Euskirchen E (2008) Vulnerability of permafrost carbon to climate change: implications for the global carbon cycle. BioScience 58:701-715

Semiletov IP, Pipko II, Shakhova NE, Dudarev OV, Pugach SP, Charkin AN, McRoy CP, Kosmach D, Gustafsson O (2011) Carbon transport by the Lena River from its headwaters to the Arctic Ocean, with emphasis on fluvial input of terrestrial particulate organic carbon vs. carbon transport by coastal erosion. Biogeosciences 8:2407-2426
Sleighter RL, Hatcher PG (2008) Molecular characterisation of dissolved organic matter (DOM) along a river to ocean transect of the lower Cheasapeake Bay by ultrahigh resolution electrospray ionization Fourier transform ion cyclotron resonance mass spectrometry. Mar Chem 110:140-152

Sleighter RL, Liu Z, Xue J, Hatcher PG (2010) Multivariate statistical approaches for the characterization of dissolved organic matter analyzed by ultrahigh resolution mass spectrometry. Environ Sci Technol 44:7576-7582

Stubbins A, Spencer RGM, Chen HM, Hatcher PG, Mopper K, Hernes PJ, Mwamba VL, Mangangu AM, Wabakanghanzi JN, Six J (2010) Illuminated darkness: molecular signatures of Congo River dissolved organic matter and its photochemical alteration as revealed by ultrahigh precision mass spectrometry. Limnol Oceanogr 55(4):1467-1477

Tarnocai C, Canadell JG, Schuur EAG, Kuhry P, Mazhitova G, Zimov S (2009) Soil organic carbon pools in the northern circumpolar permafrost region. Glob Biogeochem Cycles 23:GB2023

Thurman EM (1985) Organic geochemistry of natural waters. Boston, Hingham, MA, USA, Springer, Netherlands, Dordrecht

van Krevelen DV (1950) Graphical-statistical method for the study of structure and reaction proccesses of coal. Fuel 29:269-284

Vonk JE, van Dongen BE, Gustafsson O (2008) Lipid biomarker investigation of the origin and diagenetic state of sub-arctic terrestrial organic matter presently exported into the northern Bothnian Bay. Mar Chem 112:1-10

Vonk JE, Mann PJ, Davydov S, Davydova A, Spencer RGM, Schade J, Sobczak WV, Zimov N, Zimov S, Bulygina E, Eglinton TI, Holmes RM (2013) High biolability of ancient permafrost carbon upon thaw. Geophys Res Lett 40:2689-2693

Wickland KP, Aiken GR, Butler K, Dornblaser MM, Spencer RGM, Striegl RG (2012) Biodegradability of dissolved organic carbon in the Yukon River and its tributaries: seasonality and importance of inorganic nitrogen. Glob Biogeochem Cycles 26:GB0E03

Yunker MB, Macdonald RW, Veltkamp DJ, Cretney WJ (1995) Terrestrial and marine biomarkers in a seasonally icecovered Arctic estuary-integration of multivariate and biomarker approaches. Mar Chem 49:1-50

Zhang T, Barry RG, Knowles K, Heginbottom JA, Brown J (1999) Statistics and characteristics of permafrost and ground ice distribution in the Northern Hemisphere. Polar Geogr 23(2):147-169

Zhao-ping Y, Hua OY, Xing-Liang X, Lin Z, Ming-hua S, Caiping $Z$ (2010) Effects of permafrost degradation on ecosystems. Acta Ecol Sin 30:33-39 